NASA Technical Memorandum 100222

\title{
Reduction of Temperature Rise in High-Speed Photography
}

\author{
(MASA-TA-100222) BEDUCTIOA OP TE APERATURE \\ RISE IR HIGE-SPEED PHOTOGRAPHI (HASA) $18 \mathrm{p}$ \\ Avail: NTIS BC A03/BP AOT CSCL 14E
}

Howard A. Slater

Lewis Research Center

Cleveland, Ohio

Prepared for the

31st International Technical Symposium on Optical and Optoelectronic Applied Sciences and Engineering sponsored by the Society of Photo-Optical Instrumentation Engineers San Diego, California, August 16-21, 1987 


\title{
REDUCTION OF TEMPERATURE RISE IN HIGH-SPEED PHOTOGRAPHY
}

\author{
Howard A. Slater \\ National Aeronautics and Space Administration \\ Lewis Research Center \\ Cleveland, Ohio 44135
}

\section{SUMMARY}

This report provides information to professional industrial, scientific, and technical photographers as well as research personnel on filtration with glass and infrared-absorbing and -reflecting filters. Glass and infrared filtration is a simple and effective method to reduce the radiation heat transfer associated with continuous high-intensity tungsten lamps. The results of a filtration experiment conducted at the NASA Lewis Research Center in Cleveland, onio, are explained. The figures provide starting points for quantifying the effectiveness of various filters and associated light intensities. The combination of a spectrally selective reflector (hot or cold mirror) based on multi. layer thin-film principles and heat-absorbing or infrared opaque glass results in the maximum reduction in temperature rise with a minimum of incident light loss. The report recommends use of a voltage regulator to further control temperature rise and incident light values.

\section{INTRODUCTION}

\section{Audience and Purpose}

This report is for professional industrial, scientific, and technical photographers as well as research personnel who need information on filtration as a method of reducing radiation heat transfer. The purpose is to determine the effectiveness of glass and infrared filtration in reducing temperature rises associated with radiation heat transfer from high-intensity tungsten lamps.

\section{Scope}

The report discusses glass and infrared filtration as a simple and effective method to reduce temperature rises associated with continuous highintensity tungsten lighting in high-speed motion picture photography. The figures provide starting points for quantifying the effectiveness of glass and infrared-absorbing and-reflecting filters in reducing temperature rises. Because of time limitations methods such as vortex generators and water-cooled filters are not discussed.

\section{Research}

A filtration experiment with glass and infrared-absorbing and -reflecting filters; interviews with Ernie walker. A NASA Lewis photographic technologist, and Jerry Ling, a NASA Lewis research engineer; and reports from the library at NASA Lewis provided the major information. 


\section{Background}

According to Jerry Ling, a continuing problem in high-speed motion picture photography is adequate lighting and the associated radiation heat transfer caused by the high-intensity lights. Large temperature rises above ambient can damage subject matter and create an unsafe working environment. Because of bellows extension and the necessary increase in light the problem is compounded in macrophotography. According to Ernie walker in high-speed photography the film is generally exhausted in less than $10 \mathrm{sec}$, with most high-speed work at NASA Lewis requiring 1 to $5 \mathrm{sec}$ (approx. $100 \mathrm{ft}$ at a frame rate of $4000 \mathrm{frames} /$ $\mathrm{sec}$ is equal to $1 \mathrm{sec}$ ). The greatest temperature rise above ambient occurs in the initial $10 \mathrm{sec}$ with high-intensity tungsten bulbs. Temperature continues to rise at a reduced rate until an elapsed time of $30 \mathrm{sec}$, when it stabilizes.

\section{FILTRATION METHOD}

In a laboratory environment a high-intensity General Electric ELH tungsten bulb ( $300 \mathrm{~W}$ at $120 \mathrm{~V}$ ) was mounted on an optical bench and attached to a 10-amp Powerstat variable autotransformer. Filter holders were placed in front of a cast aluminum chamber which reduced heat lost by natural convection. The chamber contained an iron-constantan thermocouple that measured temperature in degrees Farenheit through a digital display (fig. 1). A Minolta Auto III $F$ light meter was used to measure incident light values at the thermocouple plane. All filters were manufactured by Melles Griot with the exception of the plain glass filters, which were stock items.

Temperature data were recorded at a given distance of 6 in. with no filtration to establish a constant. The lamp was operating at the maximum of $120 \mathrm{~V}$. In $5 \mathrm{sec}$ the temperature increased 74 percent to $132^{\circ} \mathrm{F}$ ( $\mathrm{fig} .2$ and table I). The incident light reading at the thermocouple plane was $\mathrm{f} / 32.5$ with ASA 25 and a shutter speed of 1/60th of a second.

Figure 3 and table II represent the spectral performance or transmittance characteristic of the Melles Griot $0^{\circ}$ and $45^{\circ}$ heat-reflecting mirrors (commonly called hot mirrors) and their respective specifications. The filters were "multilayer dielectric mirrors...operating on the same principles as interference filters (ref. 1)." The visible spectrum was represented from 350 to $700 \mathrm{~nm}$, with the infrared region extending beyond $700 \mathrm{~nm}$. High-intensity tungsten lamps generate extreme heat, approximately one-third to one-half of which is produced by longer infrared wavelengths, according to Ernie Walker.

A single $0^{\circ}$ hot mirror passed the visible spectrum and reflected infrared wavelengths back at the normal angle. Figure 4 represents this filter's configuration in the experiment. Table I and figure 5 show the effectiveness of this filter in reducing the rate of radiant heat transfer to the thermocouple. In $10 \mathrm{sec}$ a temperature of $129^{\circ} \mathrm{F}$ was achieved with filtration versus $163^{\circ} \mathrm{F}$ without filtration. This represents a temperature rise reduction of 26 percent. The incident light value at the thermocouple plane was $f / 32.3$ with ASA 25 at $1 / 60$ th of a second.

The $45^{\circ}$ hot mirror also passed the visible spectrum and reflected infrared wavelengths away at a $45^{\circ}$ angle (fig. 6). This filter allowed only a 55 percent rise above ambient to a temperature of $127^{\circ} \mathrm{F}$ (table $\mathrm{I}$ and $\mathrm{fig}$. 7) at $10 \mathrm{sec}$. This represents a temperature rise reduction of 35 percent. The 
incident light value at the thermocouple plane was $f / 32.3$ with ASA 25 at $1 / 60$ th of a second.

Heat-transmitting mirrors, commonly called cold mirrors, "reflect visible light and transmit infrared (heat)(ref. 1)." Figure 8 and table II represent the spectral response of the Melles Griot $0^{\circ}$ and $45^{\circ}$ cold mirrors and their corresponding specifications. The $0^{\circ}$ cold mirror was not tested because the test configuration was not practical. The lamp would have to be aimed directly into the mirror and the visible spectrum reflected back $180^{\circ}$ toward the subject plane. The $45^{\circ}$ cold mirror reflected visible wavelengths at a $45^{\circ}$ angle and allowed infrared wavelengths to pass through ( $f i g .9)$. This mirror reduced radiation heat transfer at $10 \mathrm{sec}$ by 54 percent, to $106^{\circ} \mathrm{F}$ versus $163^{\circ} \mathrm{F}$ (table III and fig. 10). At an elapsed time of $30 \mathrm{sec}$ a 47 percent temperature rise above ambient had occurred versus a 146 percent rise without filtration. The incident light value at the thermocouple plane was $f / 22.8$ with ASA 25 at $1 / 60$ th of a second.

The spectral response of Melles Griot's heat-absorbing glass filters is represented in figure 11. The filters are "made of heat-absorbing or infrared opaque glass (ref. 1)." Table III and figure 12 show the effectiveness of the Schott heat-absorbing filter. At $10 \mathrm{sec}$ a temperature of $105^{\circ} \mathrm{F}$ was achieved versus $163^{\circ}$ without filtration. This represents a temperature increase above ambient of only 36 percent, or a reduction in temperature rise of 55 percent. The incident light value at the thermocouple plane was $f / 22.9$ with ASA 25 at $1 / 60$ th of a second.

The effectiveness of infrared-absorbing and -reflecting filters was further demonstrated when they were compared with plain glass filters. Table IV represents the data for 1/4-in.-thick plain glass acting as a heat-reducing filter. A low 11 percent reduction in temperature rise was attained at $10 \mathrm{sec}$ versus a 55 percent reduction for the Schott heat-absorbing filter. Combining three $0.083-i n$.-thick pieces of plain glass reduced heat conduction through the filter and accordingly allowed lower temperature readings. Table IV shows that the combination of three thin layers of glass reduced temperature rise by 18 percent to a temperature of $138^{\circ} \mathrm{F}$. This is still much less than the temperature reduction achieved with the infrared-absorbing and -reflecting filters. The incident light value at the thermocouple plane was $f / 32.2$ with ASA 25 at $1 / 60$ th of a second.

A single $45^{\circ}$ hot or cold mirror in combination with the Schott heatabsorbing glass (fig. 13) produced the greatest reduction in temperature rise. At $10 \mathrm{sec}$ a temperature of $98^{\circ} \mathrm{F}$ was attained, only 26 to 27 percent above ambient. This represents a temperature rise reduction of 66 percent as compared with the temperature without filtration at $10 \mathrm{sec}$ (table $V$ ). The incident light value was $f / 22.3$ with ASA 25 at $1 / 60$ th of a second. This corresponds to a 1-1/3-stop reduction in light intensity at the thermocouple plane as compared with the intensity required without filtration.

Replacing the Schott heat-absorbing filter with 1/4-in.-thick plain glass was ineffective in reducing temperature rise (fig. 14). At $10 \mathrm{sec}$ a temperature of $116^{\circ} \mathrm{F}$ was attained with this combination (table VI) while a single Schott filter controlled temperature to $105^{\circ} \mathrm{F}$ and a $45^{\circ}$ cold mirror to $106^{\circ} \mathrm{F}$, respectively. 
Another method of controlling temperature rise in conjunction with the filters is to use a voltage regulator. If distance from the light source cannot vary and only a limited temperature rise is tolerable, a voltage regulator in combination with the filters is effective in reducing the rate of radiation heat transfer (table VII). There was significant light loss at lower voltages.

\section{SUMMARY AND RECOMMENDATIONS}

Filtration of high-intensity tungsten bulbs with infrared-absorbing and -reflecting filters is a simple and effective method of reducing temperature rises with minimum incident light loss. Because high-speed motion picture photography generally requires less than $10 \mathrm{sec}$ to exhaust the film and the major temperature rise of tungsten bulbs occurs in the first $10 \mathrm{sec}$, it is critical to control or delay this initial rate of temperature rise. Single filters cause negligible incident light loss but are less effective in reducing temperature rise than filter combinations. Because of contact resistance between surfaces a single filter composed of thin glass layers results in greater temperature reductions than a normal glass filter of equal thickness. These data indicate that infrared-absorbing or -reflecting filters and mirrors reduce the rate of radiation heat transfer (heat rise) more effectively than plain glass filters. The combination of a $45^{\circ}$ hot or cold mirror with a heat-absorbing filter results in a 66 percent reduction in temperature rise at a distance of 6 in. Incident light loss is kept to a minimum - a 1-1/3-stop increase in exposure. The figures provide professional photographers flexibility in the completion of photographic assignments that require temperature rise control with minimum light loss.

Because every photographic situation is unique, photographers should use the figures only as a starting point for determining temperature rises and associated incident light values. ASA 25 and the shutter speed of 1/60th of a second should be converted to actual photographic needs. Because of extreme temperature rises and possible shattering, glass filters less than $0.083 \mathrm{in}$. thick should not be used. Because many photographic applications cannot vary light to subject distances and only a limited temperature rise is tolerable, photographers should use a voltage regulator with the designated filter combination to reduce temperature rises.

\section{REFERENCES}

1. Optics Guide 3, Melles Griot, 1985 p. 244.

2. Walker, E.D. and Slater, H.A., Method of Reducing Temperature in High-Speed Photography. NASA TM-83620, 1984. 
TABLE I. - TEMPERATURE RISE AT 6 INCHES FROM LIGHT AND PERCENT RISE ABOVE AMBIENT FOR NO FILTER AND $0^{\circ}$ AND $45^{\circ}$ HOT MIRRORS

\begin{tabular}{|c|c|c|c|c|c|c|}
\hline \multirow{3}{*}{$\begin{array}{c}\text { Time, } \\
\text { sec }\end{array}$} & \multicolumn{6}{|c|}{ Filter } \\
\hline & \multicolumn{2}{|l|}{ None } & \multicolumn{2}{|c|}{$0^{\circ}$ Hot mirror } & \multicolumn{2}{|c|}{$45^{\circ}$ Hot mirror } \\
\hline & $\underset{{ }^{\circ}}{\text { Temperature, }}$ & $\begin{array}{l}\text { Rise, } \\
\text { percent }\end{array}$ & $\underset{{ }^{\circ}}{\text { Temperature, }}$ & $\begin{array}{l}\text { Rise, } \\
\text { percent }\end{array}$ & $\begin{array}{c}\text { Temperature, } \\
{ }^{\mathrm{F}}\end{array}$ & $\begin{array}{l}\text { Rise, } \\
\text { percent }\end{array}$ \\
\hline $\begin{array}{r}0 \\
5 \\
10 \\
15 \\
20 \\
25 \\
30\end{array}$ & $\begin{array}{r}76 \\
132 \\
163 \\
177 \\
184 \\
186 \\
187\end{array}$ & $\begin{array}{r}--- \\
74 \\
114 \\
133 \\
142 \\
145 \\
146\end{array}$ & $\begin{array}{r}76 \\
109 \\
129 \\
140 \\
144 \\
146 \\
147\end{array}$ & $\begin{array}{l}-- \\
43 \\
70 \\
84 \\
89 \\
92 \\
93\end{array}$ & $\begin{array}{r}78 \\
105 \\
121 \\
129 \\
132 \\
133 \\
134\end{array}$ & $\begin{array}{l}-- \\
35 \\
55 \\
65 \\
69 \\
71 \\
72\end{array}$ \\
\hline
\end{tabular}

TABLE II. - SPECIFICATIONS OF HEAT-REFLECTING FLAT MIRRORS

\begin{tabular}{|c|c|c|}
\hline $\begin{array}{l}\text { Angle of incidence, deg } \\
\text { Flatness, } \lambda / 25 \mathrm{~mm} \text { (at } 546 \\
\text { Dimensions, } \mathrm{mm}( \pm 0.2 \mathrm{~mm}) \\
\text { Substrate } \\
\text { Cosmetic surface quality } \\
\text { Coating. }\end{array}$ & $\begin{array}{l}\dot{\mathrm{n} m} \text { ) } \\
\dot{\cdot} \\
\dot{\cdot} \\
\dot{\cdot}\end{array}$ & 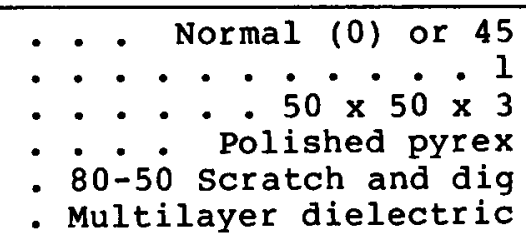 \\
\hline
\end{tabular}

TABLE III. - TEMPERATURE RISE AT 6 INCHES FROM LIGHT AND PERCENT RISE ABOVE AMBIENT FOR NO FILTER, $45^{\circ}$ HOT MIRROR, AND HEAT-ABSORBING GLASS

\begin{tabular}{|c|c|c|c|c|c|c|}
\hline \multirow{3}{*}{$\begin{array}{l}\text { Time, } \\
\text { sec }\end{array}$} & \multicolumn{6}{|c|}{ Filter } \\
\hline & \multicolumn{2}{|l|}{ None } & \multicolumn{2}{|c|}{$45^{\circ}$ Cold mirror } & \multicolumn{2}{|c|}{ Heat-absorbing glass } \\
\hline & $\begin{array}{c}\text { Temperature, } \\
{ }^{\circ} \mathrm{F}\end{array}$ & $\begin{array}{l}\text { Rise, } \\
\text { percent }\end{array}$ & $\begin{array}{c}\text { Temper ature, } \\
{ }^{\circ} \mathrm{F}\end{array}$ & $\begin{array}{c}\text { Rise, } \\
\text { percent }\end{array}$ & $\underset{{ }^{\circ} \mathrm{F}}{\stackrel{\text { Temperature }}{ }}$ & $\begin{array}{l}\text { Rise, } \\
\text { percent }\end{array}$ \\
\hline $\begin{array}{r}0 \\
5 \\
10 \\
15 \\
20 \\
25 \\
30\end{array}$ & $\begin{array}{r}76 \\
132 \\
163 \\
177 \\
184 \\
186 \\
187\end{array}$ & $\begin{array}{r}--- \\
74 \\
114 \\
133 \\
142 \\
145 \\
146\end{array}$ & $\begin{array}{r}78 \\
95 \\
106 \\
110 \\
113 \\
115 \\
115\end{array}$ & $\begin{array}{l}-- \\
22 \\
36 \\
41 \\
45 \\
47 \\
47\end{array}$ & $\begin{array}{r}77 \\
94 \\
105 \\
111 \\
114 \\
116 \\
117\end{array}$ & $\begin{array}{l}-- \\
22 \\
36 \\
44 \\
48 \\
51 \\
52\end{array}$ \\
\hline
\end{tabular}


TABLE IV. - TEMPERATURE RISE AT 6 INCHES FROM LIGHT AND PERCENT RISE ABOVE AMBIENT FOR NO FILTER, 1/4-INCH-THICK GLASS, AND THREE LAYERS OF $0.083-$ INCH-THICK GLASS

\begin{tabular}{|c|c|c|c|c|c|c|}
\hline \multirow{3}{*}{$\begin{array}{c}\text { Time, } \\
\text { sec }\end{array}$} & \multicolumn{6}{|c|}{ Filter } \\
\hline & \multicolumn{2}{|l|}{ None } & \multicolumn{2}{|c|}{ 1/4-Inch-thick glass } & \multicolumn{2}{|c|}{$\begin{array}{c}\text { Three layers of } \\
0.083-\text { inch-thick } \\
\text { glass }\end{array}$} \\
\hline & $\begin{array}{c}\text { Temperature, } \\
{ }^{\circ} \mathrm{F}\end{array}$ & $\begin{array}{c}\text { Rise, } \\
\text { percent }\end{array}$ & $\underset{{ }^{\circ}}{\text { Temper }}$ & $\begin{array}{c}\text { Rise, } \\
\text { percent }\end{array}$ & $\begin{array}{c}\text { Temperature, } \\
{ }^{\circ} \mathrm{F}\end{array}$ & $\begin{array}{c}\text { Rise, } \\
\text { percent }\end{array}$ \\
\hline $\begin{array}{r}0 \\
5 \\
10 \\
15 \\
20 \\
25 \\
30\end{array}$ & $\begin{array}{r}76 \\
132 \\
163 \\
177 \\
184 \\
186 \\
187\end{array}$ & $\begin{array}{r}74 \\
114 \\
133 \\
142 \\
145 \\
146\end{array}$ & $\begin{array}{r}79 \\
122 \\
147 \\
159 \\
164 \\
167 \\
168\end{array}$ & $\begin{array}{r}--- \\
54 \\
86 \\
101 \\
108 \\
111 \\
113\end{array}$ & $\begin{array}{r}79 \\
116 \\
138 \\
148 \\
153 \\
156 \\
158\end{array}$ & $\begin{array}{r}--- \\
47 \\
75 \\
87 \\
94 \\
97 \\
100\end{array}$ \\
\hline
\end{tabular}

TABLE V. - TEMPERATURE RISE AT 6 INCHES FROM LIGHT AND PERCENT RISE ABOVE AMBIENT FOR NO FILTER AND 45० HOT AND COLD MIRRORS - BOTH MIRRORS IN COMBINATION WITH SCHOTT HEAT-ABSORBING GLASS

\begin{tabular}{|c|c|c|c|c|c|c|}
\hline \multirow{3}{*}{$\begin{array}{l}\text { Time, } \\
\text { sec }\end{array}$} & \multicolumn{6}{|c|}{ Filter } \\
\hline & \multicolumn{2}{|l|}{ None } & \multicolumn{2}{|c|}{$\begin{array}{c}45^{\circ} \text { Hot mirror with } \\
\text { schott heat-absorbing } \\
\text { glass }\end{array}$} & \multicolumn{2}{|c|}{$\begin{array}{c}45^{\circ} \text { cold mirror with } \\
\text { Schott heat-absorbing } \\
\text { glass }\end{array}$} \\
\hline & $\begin{array}{c}\text { Temperature, } \\
{ }^{\circ} \mathrm{F}\end{array}$ & $\begin{array}{c}\text { Rise, } \\
\text { percent }\end{array}$ & $\begin{array}{c}\text { Temperature, } \\
{ }^{\circ} \mathrm{F}\end{array}$ & $\begin{array}{c}\text { Rise, } \\
\text { percent }\end{array}$ & $\begin{array}{c}\text { Temperature, } \\
{ }_{\mathrm{F}}\end{array}$ & $\begin{array}{l}\text { Rise, } \\
\text { percent }\end{array}$ \\
\hline $\begin{array}{r}0 \\
5 \\
10 \\
15 \\
20 \\
25 \\
30\end{array}$ & $\begin{array}{r}76 \\
132 \\
163 \\
177 \\
184 \\
186 \\
187\end{array}$ & $\begin{array}{r}--- \\
74 \\
114 \\
133 \\
142 \\
145 \\
146\end{array}$ & $\begin{array}{r}78 \\
90 \\
98 \\
101 \\
103 \\
104 \\
105\end{array}$ & $\begin{array}{l}-- \\
15 \\
26 \\
29 \\
32 \\
33 \\
35\end{array}$ & $\begin{array}{r}77 \\
90 \\
98 \\
103 \\
105 \\
106 \\
107\end{array}$ & $\begin{array}{l}-- \\
14 \\
27 \\
34 \\
36 \\
38 \\
39\end{array}$ \\
\hline
\end{tabular}


TABLE VI. - TEMPERATURE RISE AT 6 INCHES FROM LIGHT AND PERCENT RISE ABOVE AMBIENT FOR NO FILTER AND $45^{\circ}$ HOT MIRRORS WITH $1 / 4$-INCH-THICK

OR THREE LAYERS OF $0.083-$ INCH-THICK GLASS

\begin{tabular}{|c|c|c|c|c|c|c|}
\hline \multirow{3}{*}{$\begin{array}{l}\text { Time, } \\
\text { sec }\end{array}$} & \multicolumn{6}{|c|}{ Filter } \\
\hline & \multicolumn{2}{|l|}{ None } & \multicolumn{2}{|c|}{$\begin{array}{l}45^{\circ} \text { Hot mirror with } \\
1 / 4-\text { inch-thick glass }\end{array}$} & \multicolumn{2}{|c|}{$\begin{array}{l}45^{\circ} \text { Hot mirror with } \\
\text { three layers of } 0.083- \\
\text { inch-thick glass }\end{array}$} \\
\hline & $\underset{{ }_{F}}{\text { Temperature, }}$ & $\begin{array}{l}\text { Rise, } \\
\text { percent }\end{array}$ & $\begin{array}{c}\text { Temperature, } \\
{ }_{0} \mathrm{~F}\end{array}$ & $\begin{array}{l}\text { Rise, } \\
\text { percent }\end{array}$ & $\underset{{ }^{\circ}}{\text { Temperature, }}$ & $\begin{array}{l}\text { Rise, } \\
\text { percent }\end{array}$ \\
\hline $\begin{array}{r}0 \\
5 \\
10 \\
15 \\
20 \\
25 \\
30\end{array}$ & $\begin{array}{r}76 \\
132 \\
163 \\
177 \\
184 \\
186 \\
187\end{array}$ & $\begin{array}{r}--- \\
74 \\
114 \\
133 \\
142 \\
145 \\
146\end{array}$ & $\begin{array}{r}78 \\
101 \\
116 \\
122 \\
125 \\
126 \\
126\end{array}$ & $\begin{array}{l}-- \\
29 \\
49 \\
56 \\
60 \\
62 \\
62\end{array}$ & $\begin{array}{r}78 \\
98 \\
111 \\
116 \\
119 \\
120 \\
121\end{array}$ & $\begin{array}{l}-- \\
27 \\
42 \\
49 \\
52 \\
54 \\
55\end{array}$ \\
\hline
\end{tabular}

TABLE VII. - TEMPERATURE RISE AT 6 INCHES FROM LIGHT AND INCIDENT LIGHT FOR VOLTAGE REGULATOR WITH NO FILTER AND FOR $45^{\circ}$ COLD MIRROR AND $45^{\circ}$ HOT MIRROR WITH SCHOTT HEAT-ABSORBING GLASS

[Ambient temperature, $\left.78^{\circ} \mathrm{F}.\right]$

\begin{tabular}{|c|c|c|c|c|c|c|}
\hline \multirow{3}{*}{$\begin{array}{l}\text { Voltage, } \\
\text { V }\end{array}$} & \multicolumn{6}{|c|}{ Voltage regulator in combination with filter- } \\
\hline & \multicolumn{2}{|l|}{ None } & \multicolumn{2}{|c|}{$45^{\circ}$ Cold mirror } & \multicolumn{2}{|c|}{$\begin{array}{c}45^{\circ} \text { Hot mirror with } \\
\text { Schott heat-absorbing } \\
\text { glass }\end{array}$} \\
\hline & $\underset{{ }_{F}}{\text { Temperature, }}$ & $\begin{array}{l}\text { Incident } \\
\text { light, } \\
\text { f-stopa }\end{array}$ & $\begin{array}{c}\text { Temperature, } \\
{ }^{\circ} \mathrm{F}\end{array}$ & $\begin{array}{l}\text { Incident } \\
\text { light, } \\
\text { f-stopa }\end{array}$ & $\begin{array}{c}\text { Temperature, } \\
{ }^{\circ} \mathrm{F}\end{array}$ & $\begin{array}{l}\text { Incident } \\
\text { light, } \\
\text { f-stop }\end{array}$ \\
\hline $\begin{array}{r}60 \\
70 \\
80 \\
90 \\
100 \\
110 \\
120\end{array}$ & $\begin{array}{l}108 \\
119 \\
129 \\
142 \\
156 \\
172 \\
189\end{array}$ & $\begin{array}{l}11.2 \\
16.2 \\
16.6 \\
22.4 \\
22.9 \\
32.1 \\
32.5\end{array}$ & $\begin{array}{r}89 \\
92 \\
96 \\
100 \\
105 \\
112 \\
118\end{array}$ & $\begin{array}{r}8.6 \\
11.6 \\
16.3 \\
16.8 \\
22.3 \\
22.7 \\
32.0\end{array}$ & $\begin{array}{r}84 \\
86 \\
89 \\
93 \\
96 \\
100 \\
105\end{array}$ & $\begin{array}{r}8.5 \\
11.2 \\
11.7 \\
11.9 \\
16.5 \\
16.8 \\
22.3\end{array}$ \\
\hline
\end{tabular}

a For ASA 25 at $1 / 60$ th of a second. 


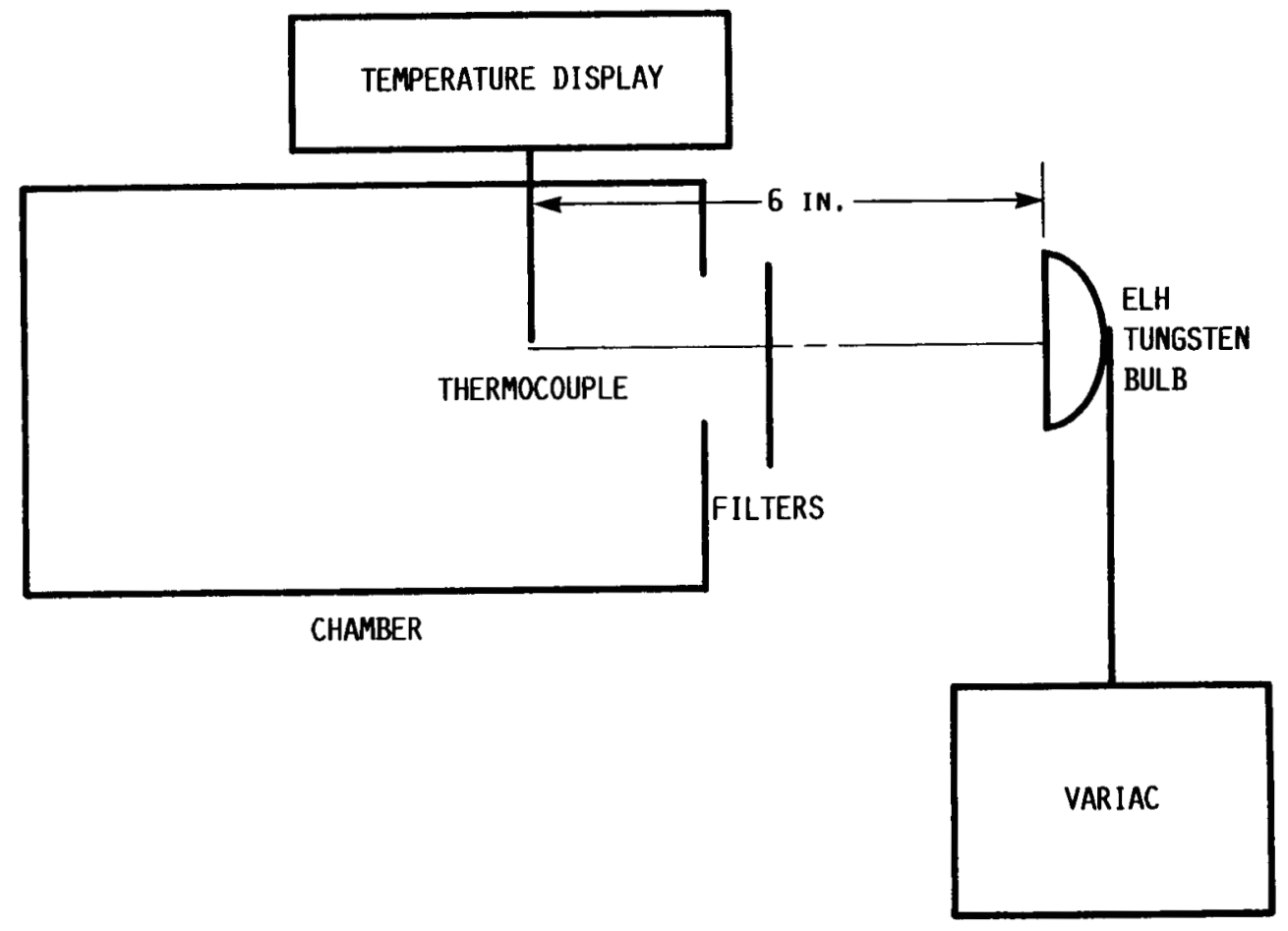

FIGURE 1. - TEST CONFIGURATION.

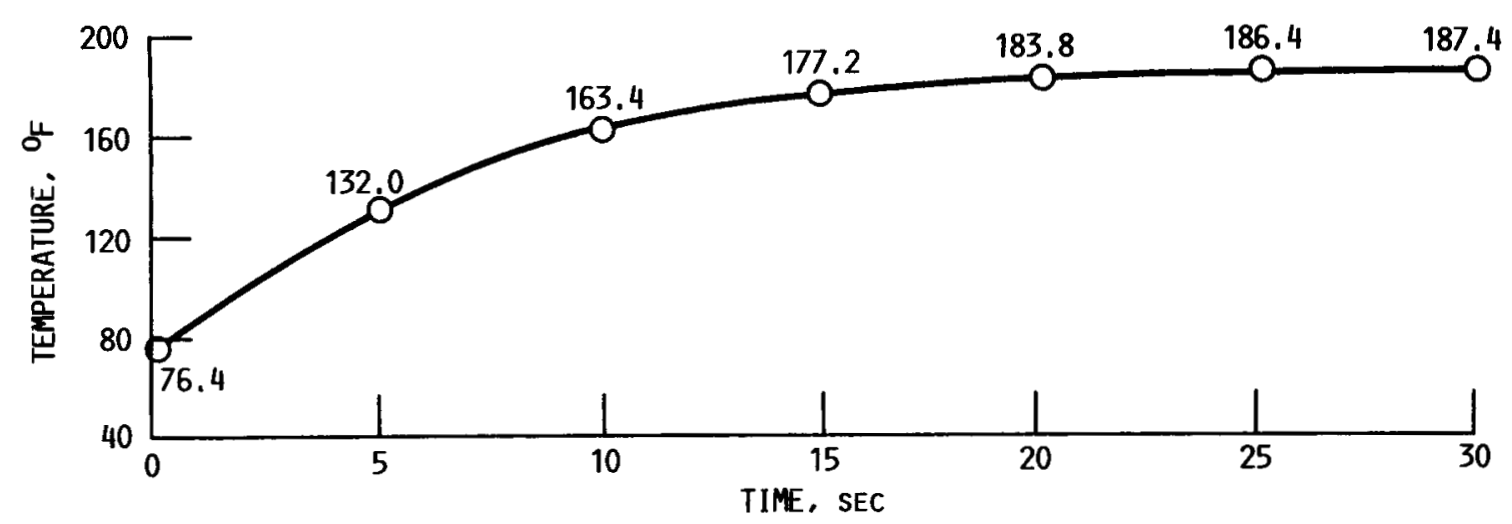

FIgURE 2. - TEMPERATURE RISE AT A DistanCE OF 6 In. FROM LIGHT WITH NO FILTRATION. 


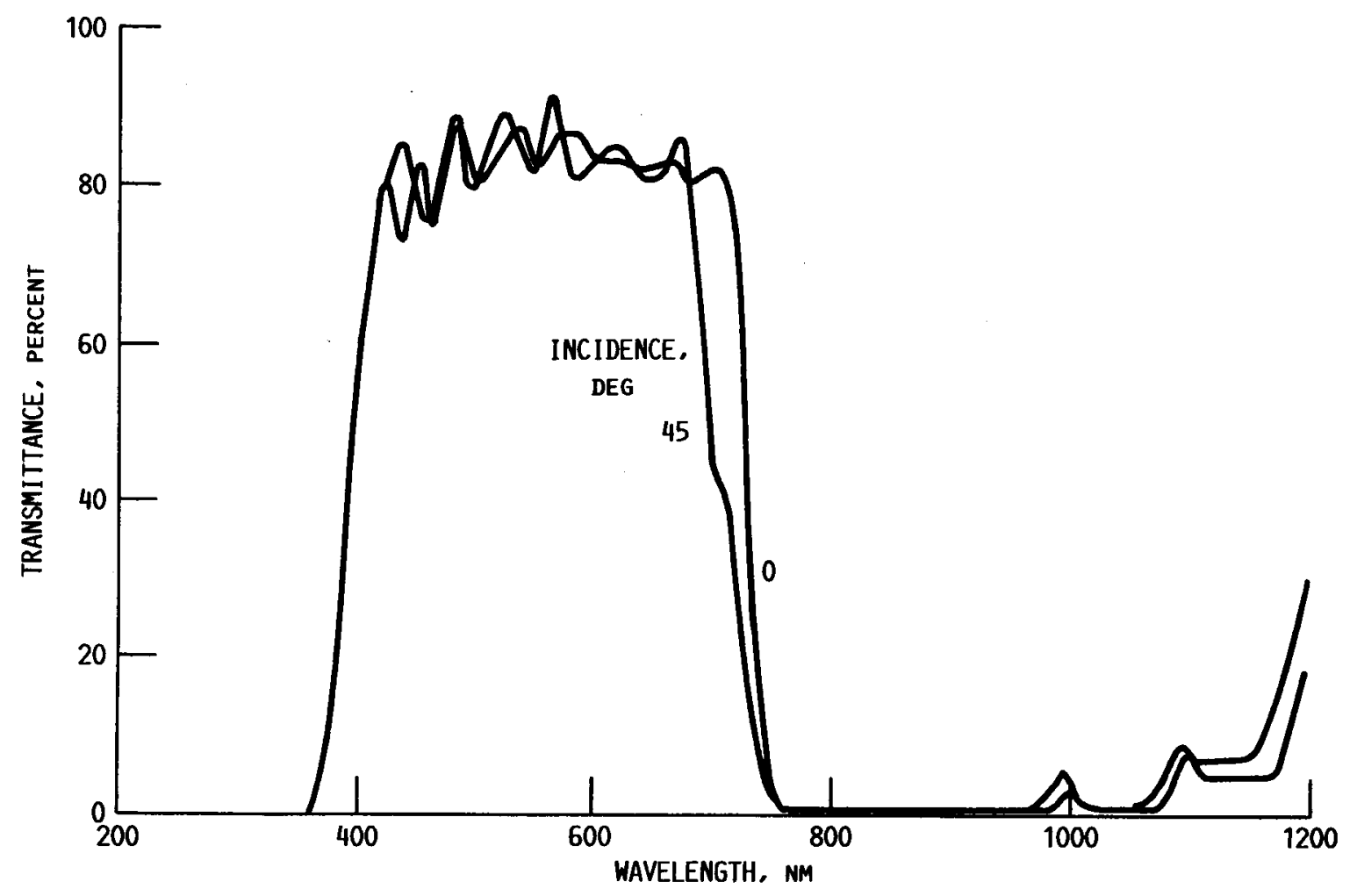

FIGURE 3. - SPECTRAL PERFORMANCE OF $0^{\circ}$ AND $45^{\circ}$ HEAT-REFLECTING (HOT) FLAT MIRRORS. (DATA FROM REF. 1.)

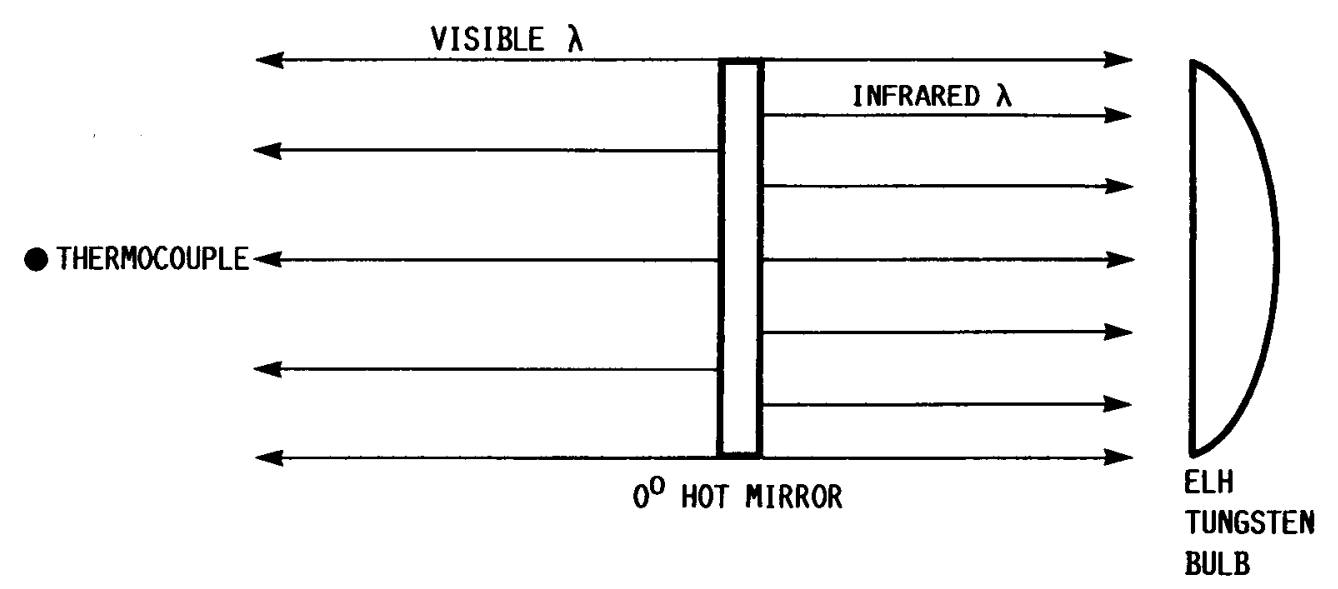

FIGURE $4 .-0^{\circ}$ HOT MIRROR CONFIGURATION. 


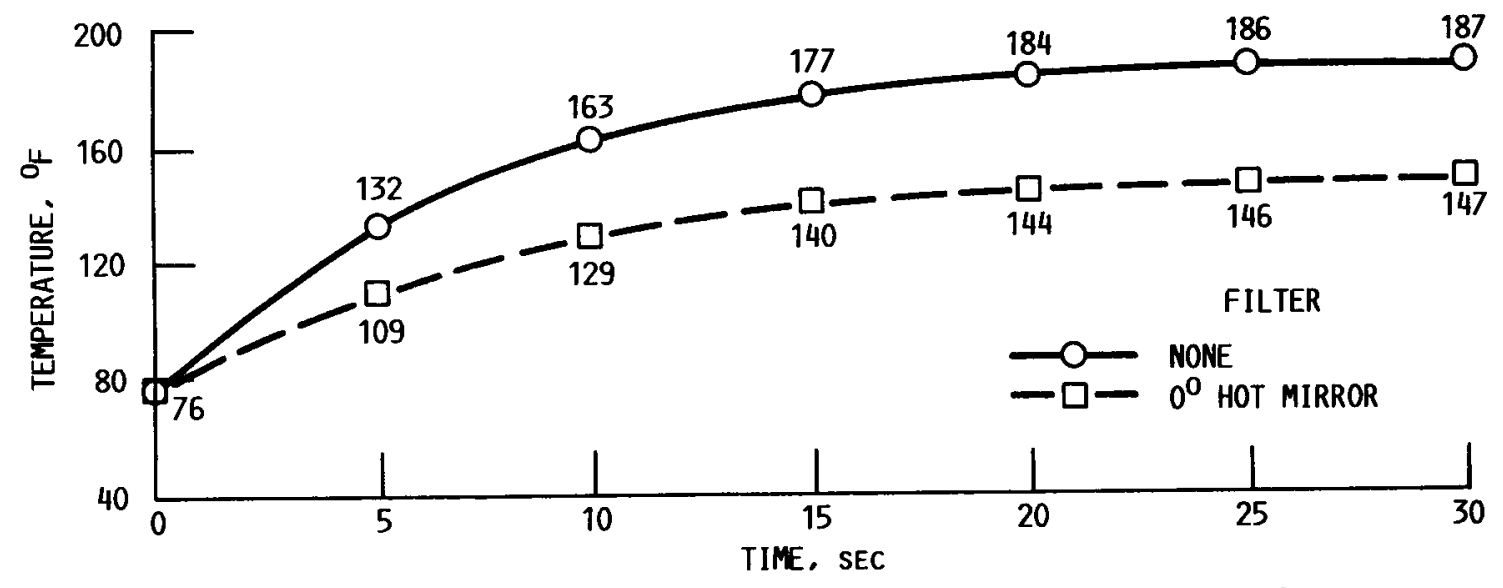

FIGURE 5. - TEMPERATURE RISE AT A DISTANCE OF 6 IN. FROM LIGHT FOR A $0^{0}$ HOT MIRROR.

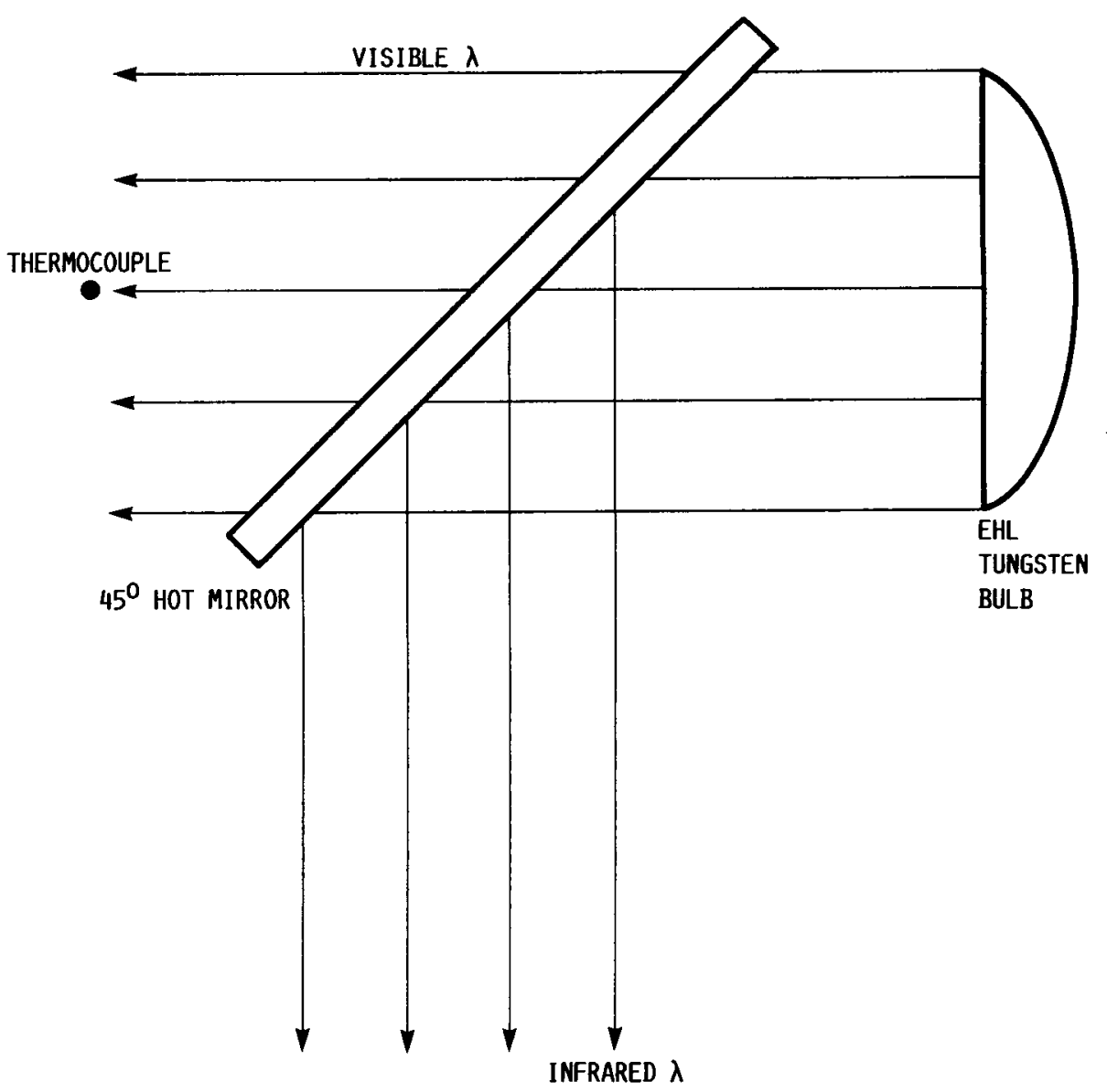

FIGURE 6. $-45^{\circ}$ HOT MIRROR CONFIGURATION. 


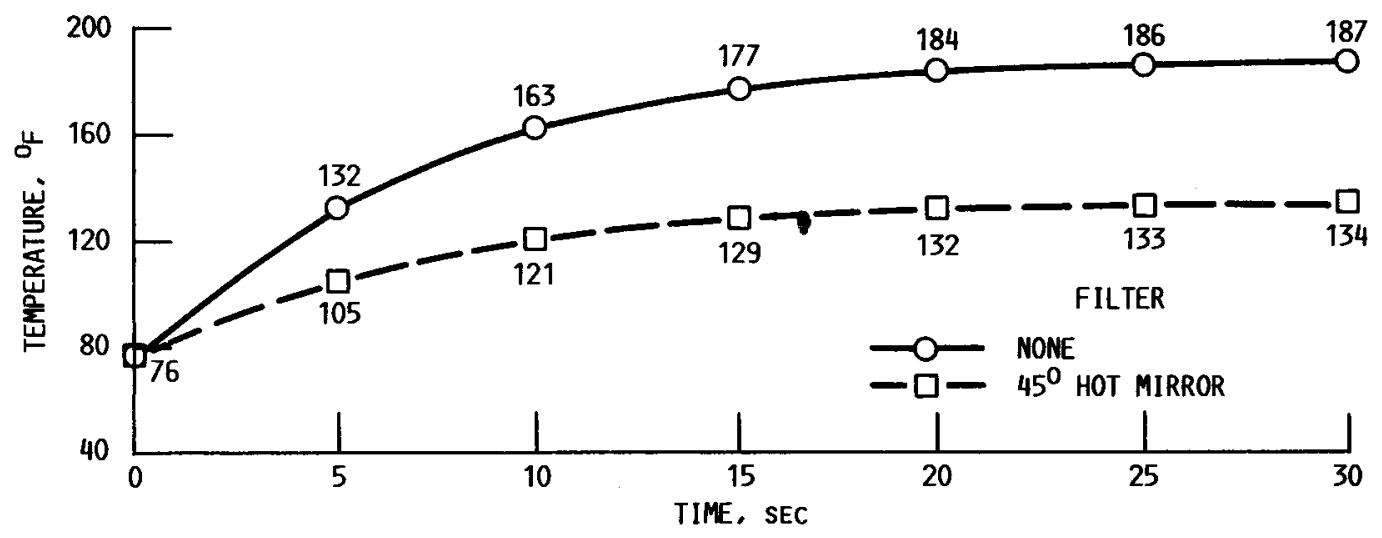

FIGURE 7. - TEMPERATURE RISE AT A DISTANCE OF 6 IN. FROM LIGHT FOR $45^{\circ}$ HOT MIRROR.

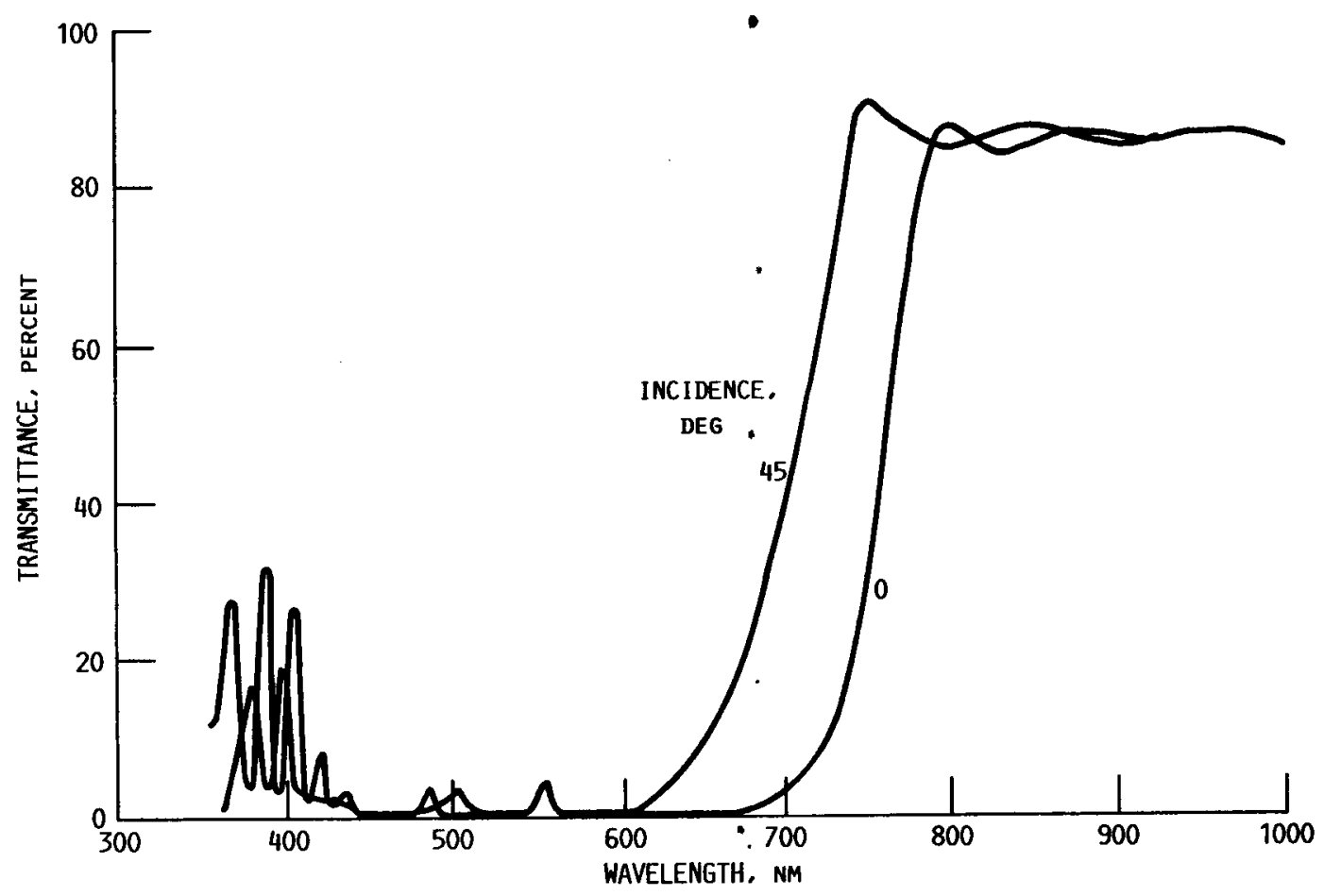

FIgURE 8. - SPECTRAL PERFORMANCE OF $0^{\circ}$ AND $45^{\circ}$ HEAT-TRANSMITTING (COLD) FLAT MIRRORS. (DATA FROM REF. 1.) 


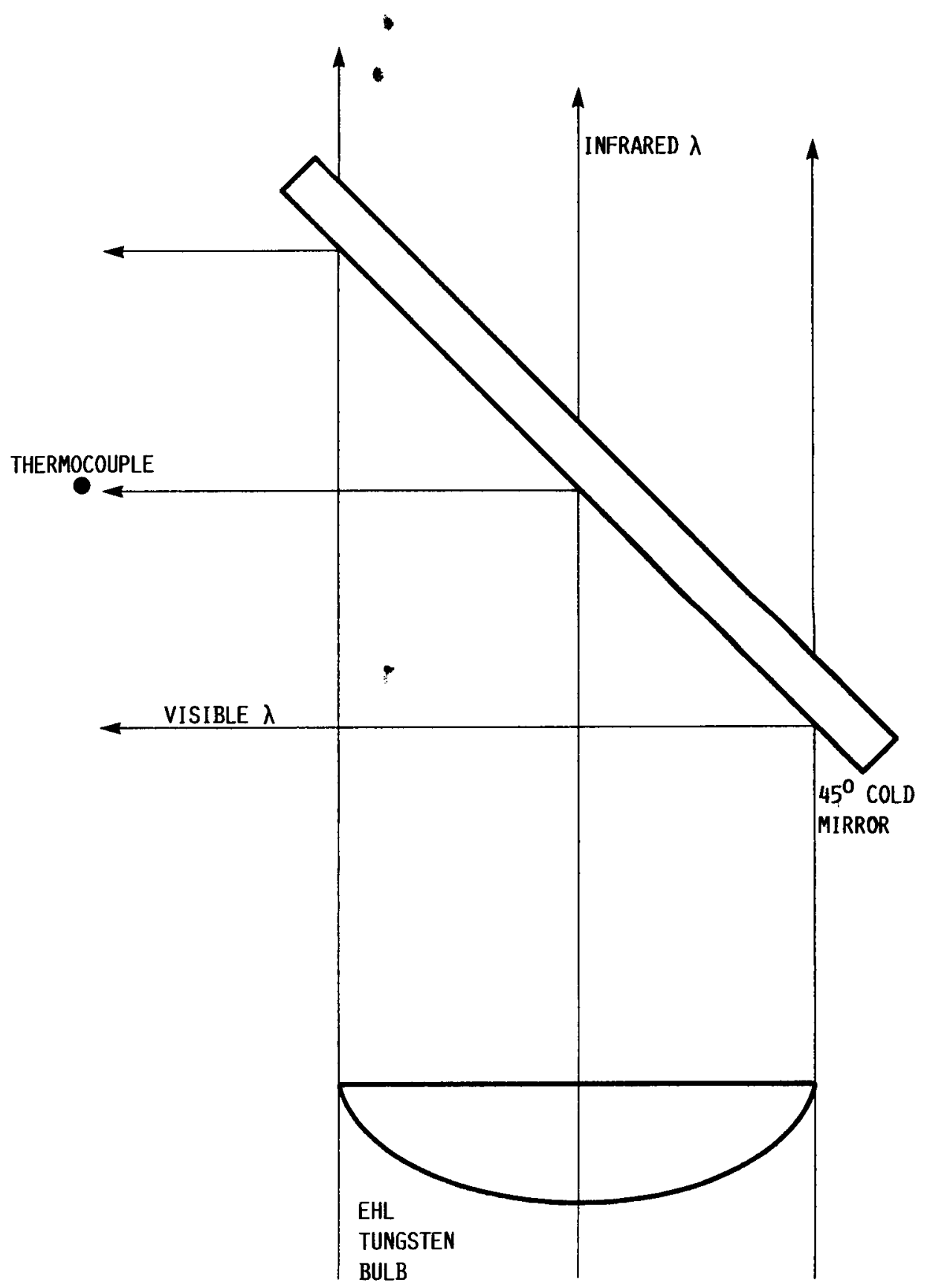

FIGURE 9. $-45^{\circ}$ COLD MIRROR CONFIGURATION. 
FILTER

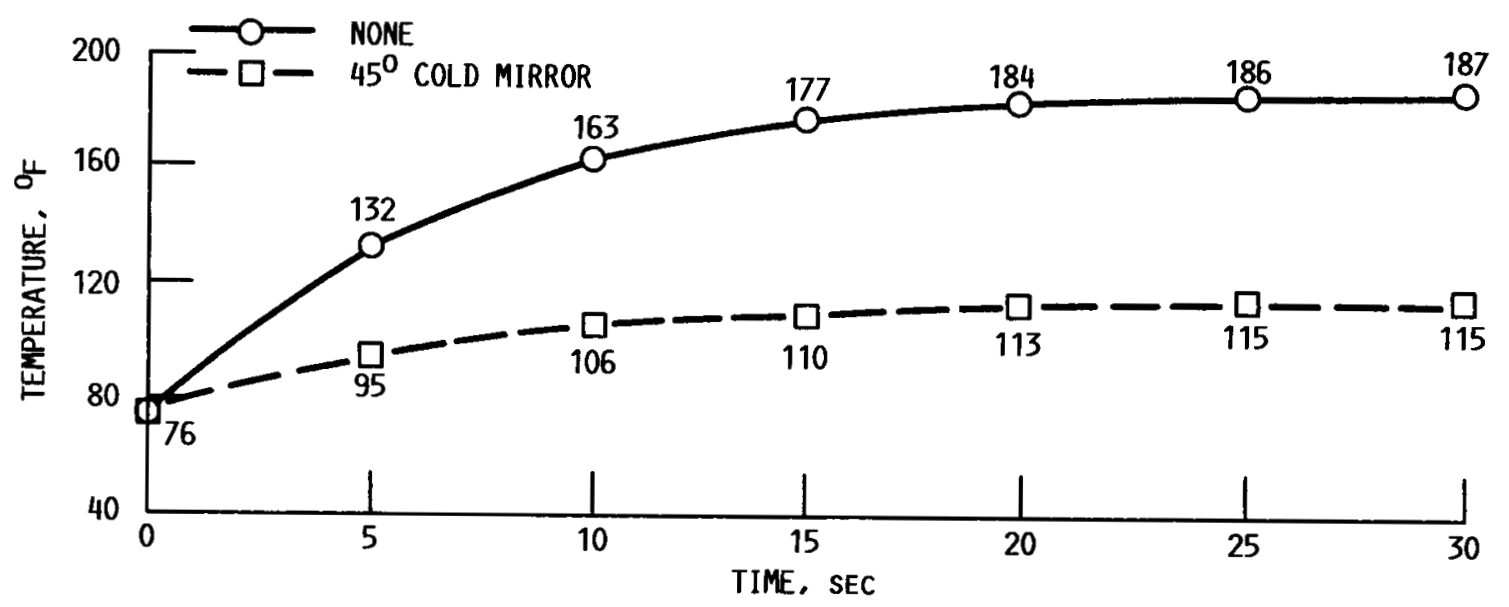

FIgURE 10. - TEMPERATURE RISE AT A DISTANCE OF 6 IN. FROM LIGHT FOR $45^{\circ}$ COLD MIRROR. 


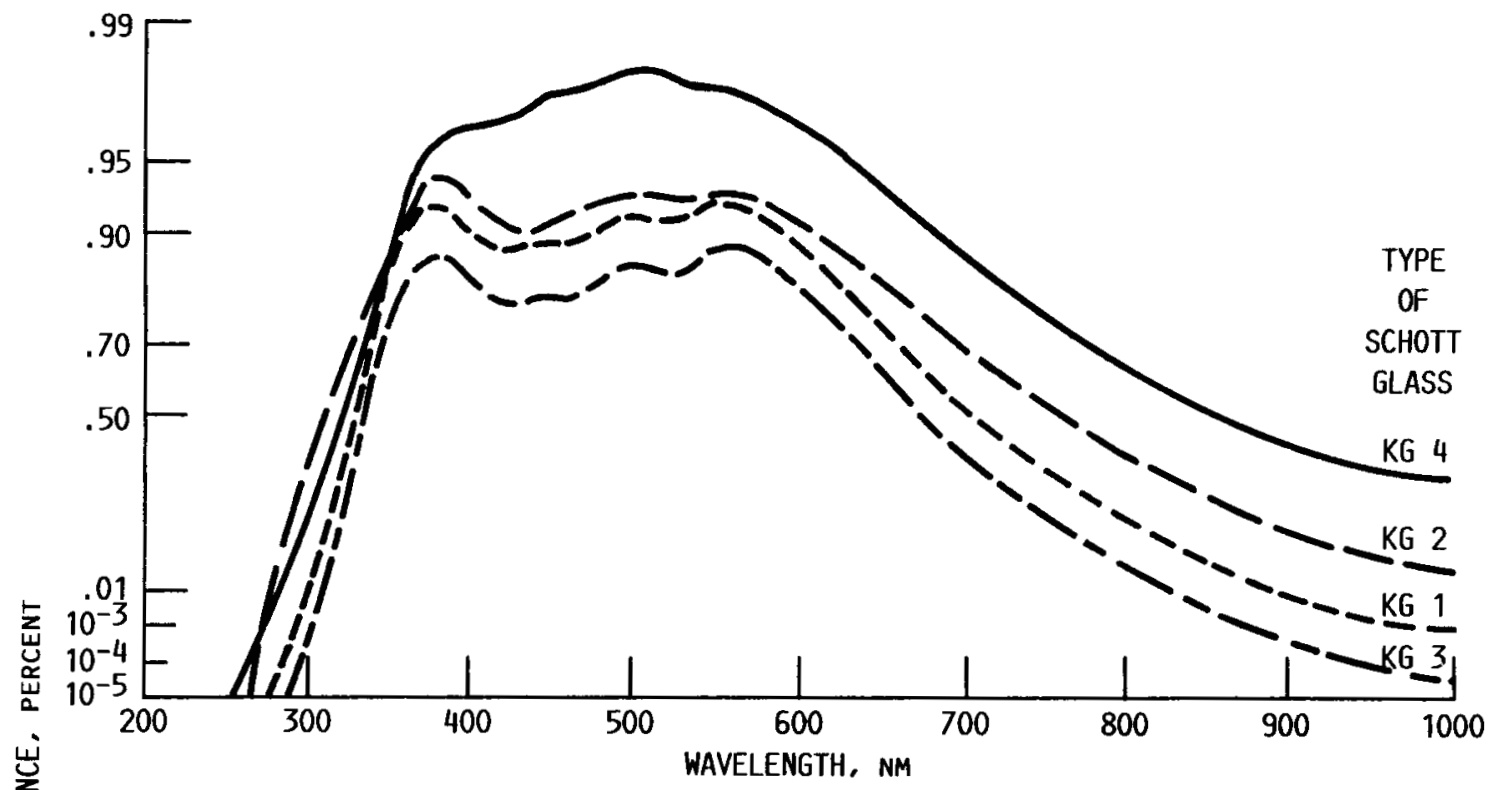

(A) VISIBLE RANGE.

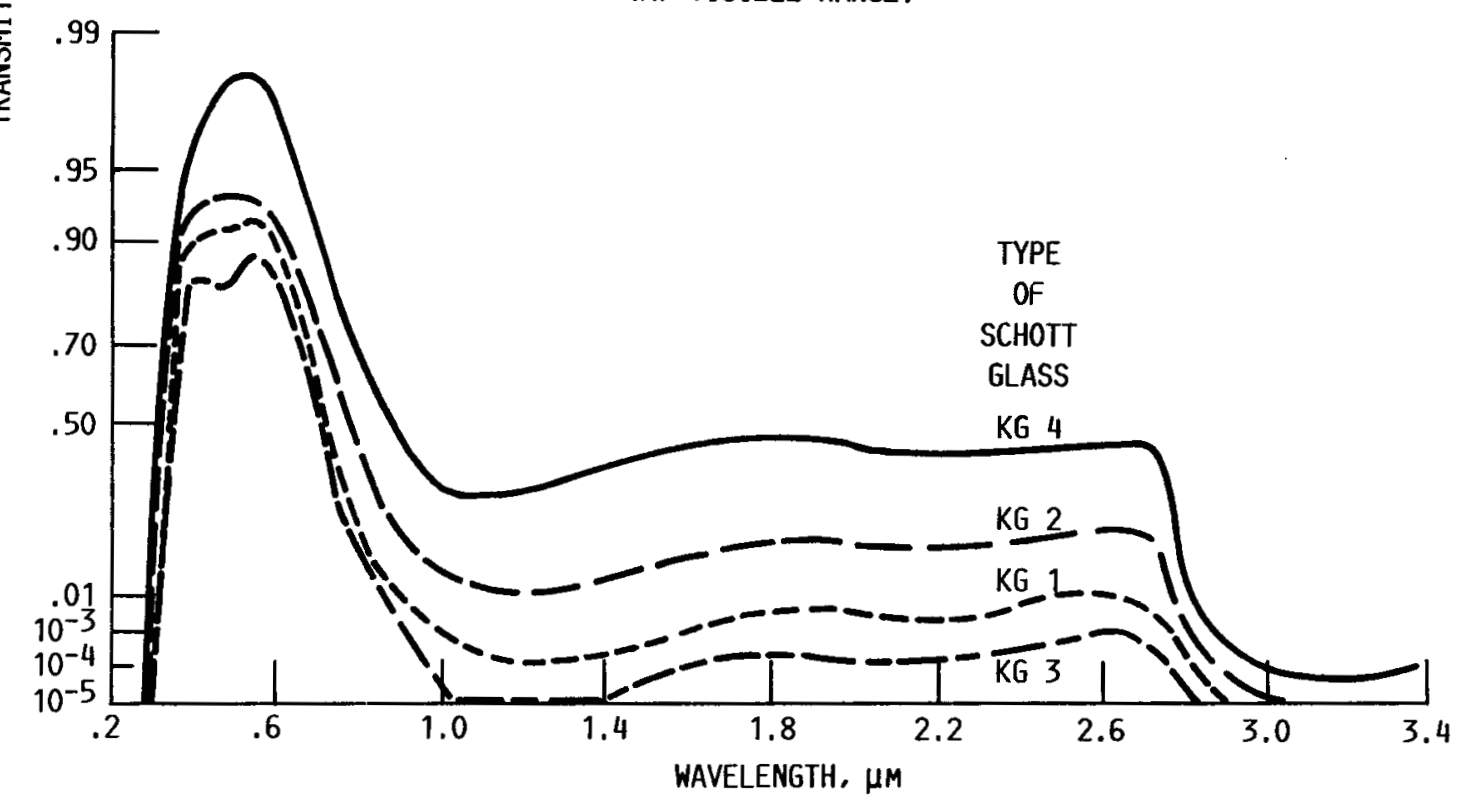

(B) EXTENDED RANGE.

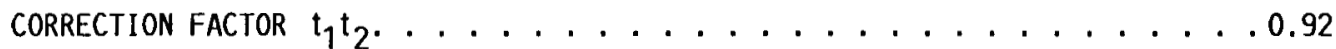
DIMENSIONS, MM $( \pm 0.25 \mathrm{MM}) \ldots \ldots . \ldots \ldots 0 \times 50 \times 3$

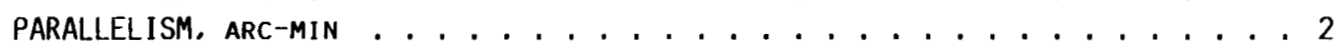
MATERIAL. . . . . . . . . . . . . . . . . . SCHOTT KG GLASS COSMETIC SURFACE QUALITY. . . . . . . . . PITCH POLISHED, 8-50 SCRATCH AND DIG SUGGESTED MAXIMUM OPERATING TEMPERATURE, ${ }^{0} \mathrm{C}\left({ }^{0} \mathrm{~F}\right) \ldots \ldots$. . . . . 250 (482)

(C) SPECIFICATIONS.

FiguRE 11. - SPECTRAL PERFORMANCE AND SPECIFICATIONS OF MELLES GRIOT HEAT-ABSORBING GLASS FILTERS. 


\section{FILTER}

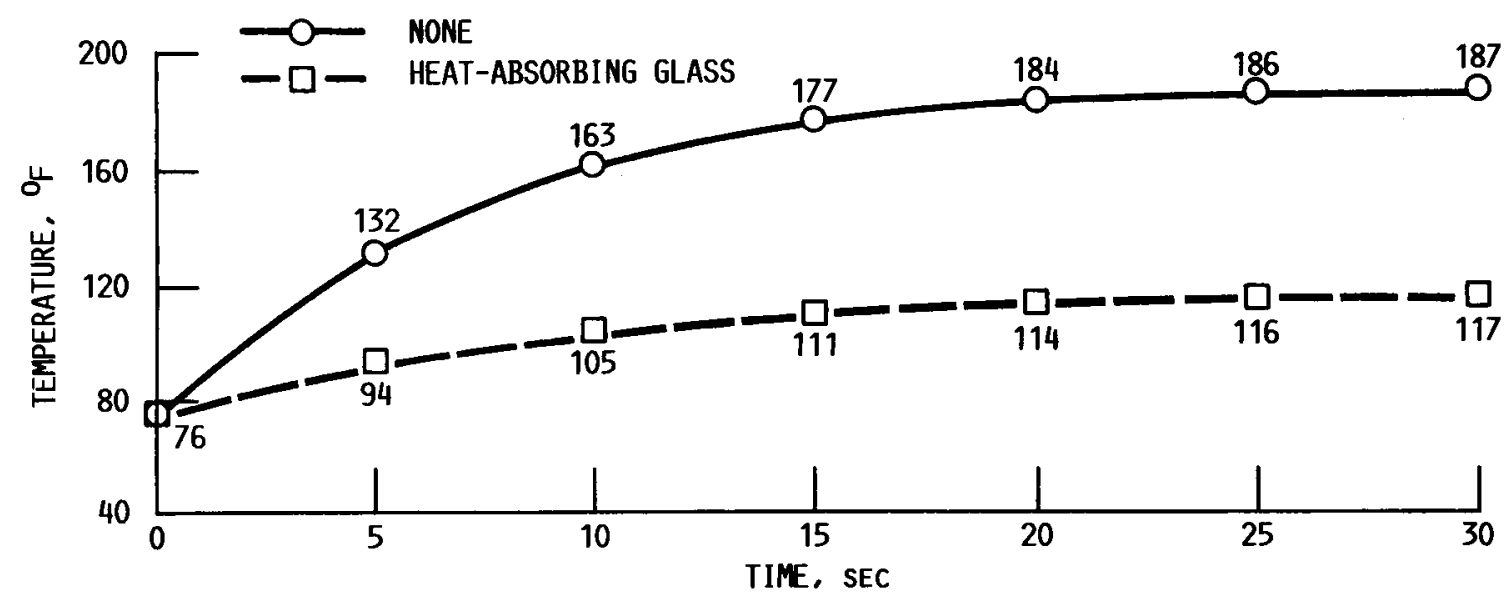

FIGURE 12. - TEMPERATURE RISE AT A DISTANCE OF 6 IN. FROM LIGHT FOR SCHOTT HEATABSORBING GLASS FILTER.

\section{FILTER}

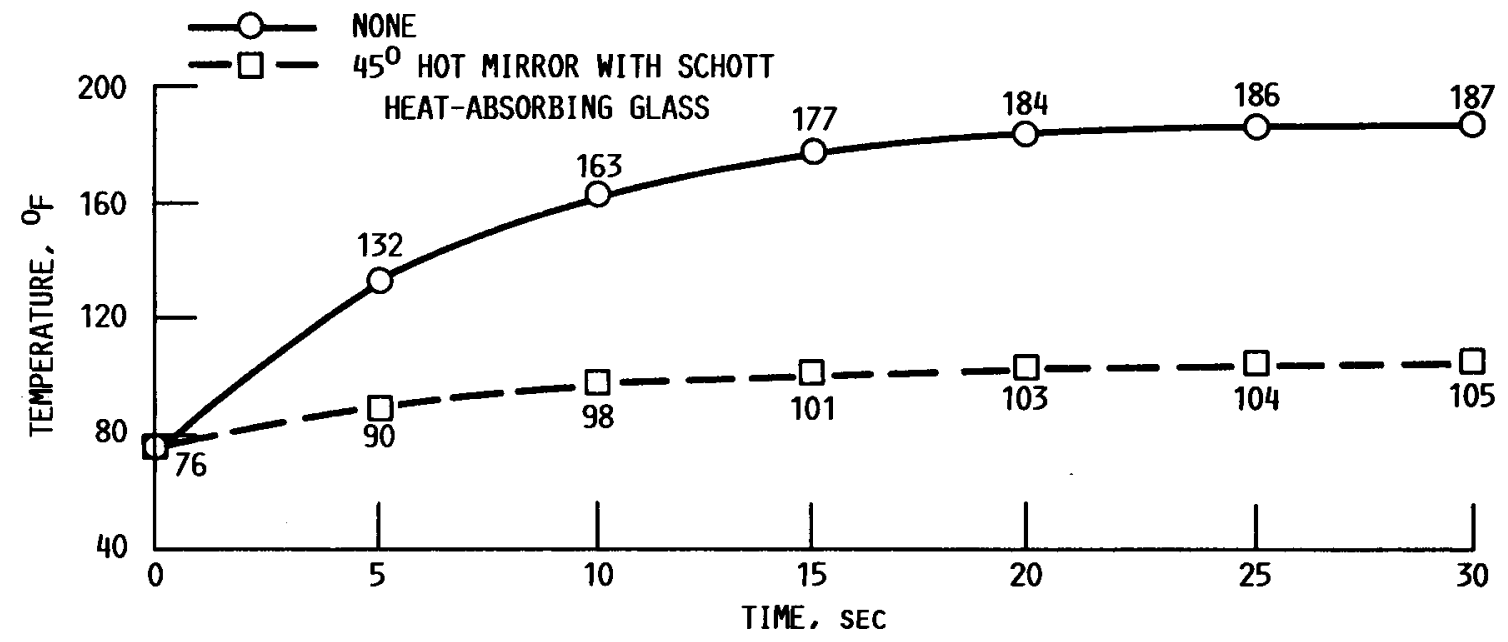

FIGURE 13. - TEMPERATURE RISE AT A DISTANCE OF 6 IN. FROM LIGHT FOR $45^{\circ}$ HOT MIRROR WITH SCHOTT HEAT-ABSORBING GLASS FILTER.

FILTER

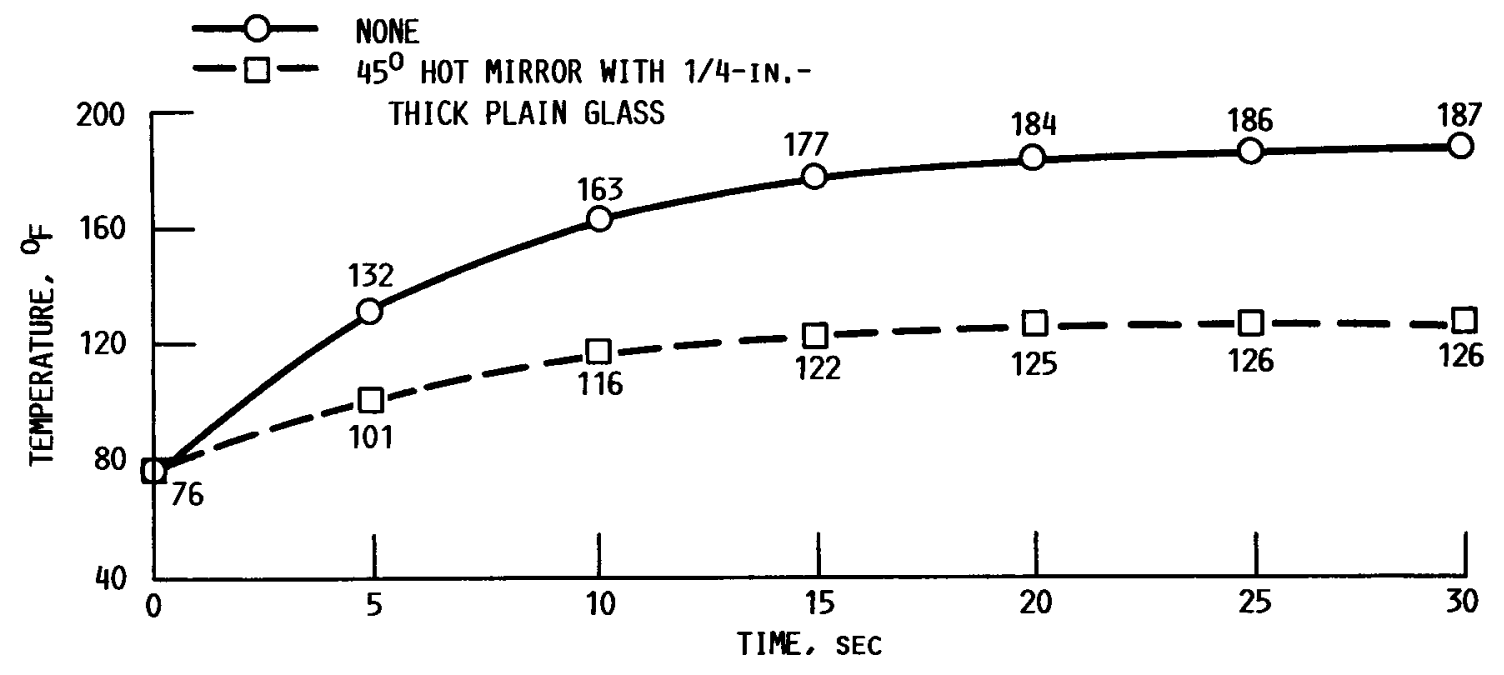

FIGURE 14. - TEMPERATURE RISE AT A DISTANCE OF 6 IN. FROM LIGHT FOR $45^{\circ}$ HOT MIRROR WITH 1/4-IN.-THICK PLAIN GLASS FILTER. 


\begin{tabular}{|c|c|c|c|c|}
\hline \multirow{2}{*}{ 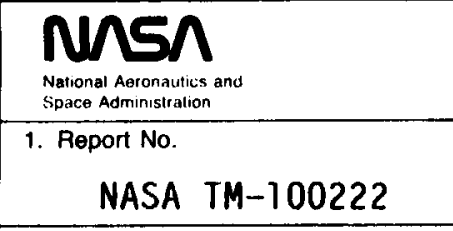 } & \multicolumn{4}{|c|}{ Report Documentation Page } \\
\hline & \multicolumn{2}{|c|}{ 2. Government Accession No. } & \multicolumn{2}{|c|}{ 3. Recipient's Catalog No. } \\
\hline \multicolumn{3}{|c|}{$\begin{array}{l}\text { 4. Title and Subtitle } \\
\text { Reduction of Temperature Rise in High-Speed } \\
\text { Photography }\end{array}$} & \multicolumn{2}{|c|}{ 6. Performing Organization Code } \\
\hline \multirow[t]{2}{*}{$\begin{array}{l}\text { 7. Author(s) } \\
\text { Howard A. Slater }\end{array}$} & & & \multicolumn{2}{|c|}{$\begin{array}{l}\text { 8. Performing Organization Report No. } \\
\qquad E-3666\end{array}$} \\
\hline & & & \multicolumn{2}{|c|}{$\begin{array}{l}\text { 10. Work Unit No. } \\
\text { None } \\
\end{array}$} \\
\hline \multirow{2}{*}{\multicolumn{3}{|c|}{$\begin{array}{l}\text { 9. Pertorming Organization Name and Address } \\
\text { National Aeronautics and Space Administration } \\
\text { Lewis Research Center } \\
\text { Cleveland, Ohio } 44135-3191\end{array}$}} & \multirow{2}{*}{\multicolumn{2}{|c|}{\begin{tabular}{|} 
11. Contract or Grant No. \\
13. Type of Report and Period Covered \\
Technical Memorandum \\
\end{tabular}}} \\
\hline & & & & \\
\hline \multicolumn{3}{|c|}{$\begin{array}{l}\text { 12. Sponsoring Agency Name and Address } \\
\text { National Aeronautics and Space Administration } \\
\text { Washington, D.C. 20546-0001 }\end{array}$} & \multicolumn{2}{|c|}{ 14. Sponsoring Agency Code } \\
\hline \multicolumn{5}{|c|}{$\begin{array}{l}\text { Prepared for the } 31 \text { st International Technical Symposium on Optical and Opto- } \\
\text { electronic Applied Sciences and Engineering, sponsored by the Society of Photo- } \\
\text { Optical Instrumentation Engineers, San Diego, California, August 16-21, 1987. }\end{array}$} \\
\hline \multicolumn{5}{|c|}{$\begin{array}{l}\text { 16. Abstract } \\
\text { This report provides information to professional industrial, scientific, and } \\
\text { technical photographers as well as research personnel on filtration with glass } \\
\text { and infrared-absorbing and -reflecting filters. Glass and infrared filtration } \\
\text { is a simple and effective method to reduce the radiation heat transfer associ- } \\
\text { ated with continuous high-intensity tungsten lamps. The results of a filtra- } \\
\text { tion experiment conducted at the NASA Lewis Research Center in Cleveland, } \\
\text { ohio, are explained. The figures provide starting points for quantifying the } \\
\text { effectiveness of various filters and associated light intensities. The combi- } \\
\text { nation of a spectrally selective reflector (hot or cold mirror) based on multi- } \\
\text { layer thin-film principles and heat-absorbing or infrared opaque glass results } \\
\text { in the maximum reduction in temperature rise with a minimum of incident light } \\
\text { loss. The report recommends use of a voltage regulator to further control tem- } \\
\text { perature rise and incident light values. }\end{array}$} \\
\hline \multicolumn{2}{|c|}{$\begin{array}{l}\text { 17. Key Words (Suggested by Author(s)) } \\
\text { Filtration; Glass filtration; Infrared } \\
\text { absorption; IR reflection; Heat } \\
\text { reduction }\end{array}$} & \multicolumn{3}{|c|}{$\begin{array}{l}\text { 18. Distribution Statement } \\
\text { Unclassified - Unlimited } \\
\text { Subject Category } 35\end{array}$} \\
\hline $\begin{array}{l}\text { 19. Security Classif. (of this report) } \\
\text { Unclass if ied }\end{array}$ & $\begin{array}{r}\text { Security Classif. (of this } \\
\text { UnC }\end{array}$ & ssified & $\begin{array}{r}\text { 21. No of pages } \\
\frac{16}{6} \\
\end{array}$ & $\begin{array}{r}\text { 22. Price* } \\
\text { A02 }\end{array}$ \\
\hline
\end{tabular}

